\title{
Appraisal of Geodiversity of Kansai-Tangai Interfluves Area (Paschim Medinipur District, West Bengal) using Remote Sensing Data and GIS tools: An Effort to Forward Landscape Management
}

\author{
Ansar Khan ${ }^{1}$, Soumendu Chatterjee ${ }^{2}$, Nilay Kanti Barman ${ }^{3}$ \\ ${ }^{I}$ Department of Geography and Environment Management, Vidyasagar University, India \\ ${ }^{2}$ Department of Geography, Presidency University, India \\ ${ }^{3}$ Department of Geography and Environment Management, Vidyasagar University, India
}

\begin{abstract}
Landscape Character is a distinct and recognizable pattern of elements that occur consistently in a particular type of landscape. Particular combination of geology, landform, soils, vegetation, land use, field patterns and human settlement create character. Land is limited resource and therefore land has become more valuable than ever. Land use pattern is changing, deforestation is occurred, settlement and agricultural practices is increased and that demands more land. Increased understanding of human impacts on nature and environment underlines importance of sustainable land use and planning. In that perspective the importance of landscape analysis and understanding of interaction of nature factors and human activities become more and more significant. The aim of the study is to provide an assessment and description of the character, distinctiveness and qualities of the landscape and geodiversity of Kansai-Tangai interfluves area of Paschim Midnapore District, identifying their component landscape types and character areas and to identify factors of change that have influenced landscape change in the past, factors currently play a important role to change the landscape and those, which will influence change in the future. This study has also been included outside factors which impact locally.
\end{abstract}

Keywords: Component Landscape; Geodiversity; Human Impact; Interfluves; Landscape Character

\section{Introduction}

Landscape as defined by Gordon, J.E., Brazier, V. and Lees, R.G. (1994) is a mosaic of "interacting ecosystems". There is increasing recognition that the spatial structure of landscape elements is a factor of critical significance in determining biodiversity and achieving sustainable development (World Conservation Monitoring Centre, 1992). This is also highlighted by recent European legislation (e.g. PEBDLS) which now considers the conservation status of the wider countryside, including both its biological and landscape diversity. An approach that exhibits potential for biodiversity assessment is Landscape Character Mapping. Landscape Character is a discrete and decipherable pattern of elements that occur consistently in a particular type of landscape. Particular combination of geology, landform, soils, vegetation, land use and human settlement create character". The relation behind landscape character mapping is that particular combinations of physical and cultural factors occurring in different areas result in similar landscapes. The approach is based on a series of natural (e.g. landform, geology, soils) and cultural factors (e.g. land use, settlement pattern) that are used to describe the variability in the landscape at various spatial scales depending on the research scope. The development of landscape character assessment/mapping has been facilitated by the use of GIS as a decision support tool. This technology provides significantly increased opportunities for more detailed environmental resource inventory and analysis in space and time and shows considerate promise for extensive use in nature conservation (Turner, 1998). The different steps are taken for the development of landscape topological framework through mapping of spatial distributions like; Sal, Mahua and Abitat species. It presents the results of the first part of mapping based on physical attributes of the landscape, while the derivation and incorporation of the cultural attributes is discussed. The application of GIS can assist in the formulation of landscape character assessment and therefore land use policies through the development of an integrated spatial database of land use in the Kansai- Tangai interfluves area of Paschim Medinipur.

\subsection{Geodiversity}

Geological and geomorphological conservation (geoconservation) have a long history. In the first 20 years of the nineteenth century, the quarrying of stone from Salibury Crags in Edinbrurg, Scotland was having such a serious impact on the city landscape that legal action was taken in 1819 to prevent further deterioration (McMillan et al., 1999). Germany established the first geological nature reserve in the world at Siebengebirge as early as 1836. Some of the first specific geological sites to be protected were also in Scotland where city 
Council acted to enclose Agassiz Rock Striations in Edinburg (1880). Geologist and Geomorphologist started using the term "geodiversity" in the 1990s to describe the variety within abiotic nature. The major attention being given to biodiversity and wildlife conservation was simply reinforcing the long-standing imbalance within nature conservation policy and practice between the biotic and abiotic elements of nature. Although geological and geomorphological conservation had been practiced for over 100 years, these were usually the "Cinerrella" of nature conservation (Gray, 1997a). Many international conservation organization, although using the general term "nature conservation" and focused most or all of their attention on the latter. Milton (2002) summarized the situation well in stating the "Diversity in nature is usually taken to mean diversity of living nature." It is difficult to trace the first usage of the term "geodiversity", indeed it is likely that several earth scientists coined the term independently, as a natural twin to the term "biodiversity". Some of the first uses appear to have been Tasmania, Australia. Kevin Kiernan (1997a) was using the term "landform diversity" and "geomorphic diversity" in the 1980s and drawing analogies with biological concepts by using terms such as "landform species" and "landform communities". The term "geodiversity" was used by Sharples (1993), Kiernan (1994, 1996, 1997a) and Dixon (1995, 1996a, b) in studies of geological and geomorphological conservation in Tasmania, in particular, or Australia, in general. Australian Heritage Commission (2002) has defined it as "the range or diversity of geological (bedrock), geomorphological (landform) and soil features, assemblages, systems and processes". The term is now very well understood in Tasmanian nature conservation. Sharples (2002a) stress the importance of distinguishing the terms "geodiversity", "geoconservation" and "geoheritage". He defines them as follows:

- "Geodiversity" is the quality we are trying to conserve.

- "Geoconservation" is the endeavor of trying to conserve it, and

- "Geoheritage" comprises concrete examples of it which may be specifically identified as having conservation significance.

\section{Need for Conserving Landscape Character}

Landscape character is a recognized component of sustainable development and has become a significant material consideration in policy formulation and development control decisions. The character approach also helps to priorities land management and enhancement measures which can immensely help the economy as well as sustaining the environment of the Kansai-Tangai Interfluves Area. The LCA will be used to:

- Inform the development and implementation of National Park Management Plan policies, conservation and grant aid schemes and land use planning policies.

- Act as a tool for spatial planning use within the Park and the development and implementation of the Authority's Local Development Framework.

- Develop future strategies for conserving and/or enhancing the landscape, local distinctiveness and sense of place.

- Provide a point of reference for landscape design and management issues.

- Provide an assessment that can inform and respond to other landscape, cultural and historical strategies.

- Informing and developing land-use policy such as development and targeting of agro-environment scheme measures.

- Assessing the sensitivity and capacity of landscapes to accommodate new development.

- Planning guidance in determining planning application and development proposal.

- Possible adoption as Supplementary Planning Document within the LDF

- Development of more detailed evidence base at a local level to inform area action plans/village design statements.

- The LCA also has the long-term potential to form the backbone of various others Initiatives and assessments such as sensitivity and capacity studies, tranquillity and Wilderness assessments and design policy.

\section{Study Area}

The study area includes Kansai - Tangai interfluves area of Paschim Medinipur District, West Bengal. The study area covers area of about 142519.76 hector Stretching between $86^{\circ} 58^{\prime} 02^{\prime \prime}$ E, $22^{\circ} 22^{\prime} 17^{\prime \prime} \mathrm{N}$ to $87^{\circ} 40^{\prime} 17^{\prime \prime E}, 22^{\circ} 46^{\prime} 22^{\prime \prime} \mathrm{N}$. From the administrative point of view, these areas cover six blocks of central part of Paschim Medinipur District. The district lies north of the Kansai River and its agricultural-trade centre is on the Grand Trunk Road from Kolkata to Amritsar. Kharagpur Railway Junction, across the river, provides major rail connections (Second Working plan, 1995-2015, Midnapore). The topography, soil, Vegetation, drainage pattern, climate has been playing an important role in growth of the region. The study area is surrounded in the north by 
Garbeta - I, III, blocks, Chandrakona - II block and in the south by Jhargram, Kharagpur - I, II, blocks and in the east by Debra, Daspur - II, blocks and in the west by Binpur - II, and Jamboni blocks of Paschim Medinipur District. As a result of increasing of population, unscientific agricultural practices and other land uses practices, increased deforestation and decreased ground water level. Where agriculture is less and amount of vegetation is high people destroyed vegetation to maintain their life. But due to decrease of physical state of the environment the landscape of an area becomes changed. In the study area (Kansai-Tangai interfluves area) different types of human activities (deforestation, unscientific agricultural practices, excavetory works) are affecting on physical aspects of the environment. Western part of Paschim Medinipur district is covered by natural forest and good composition of lateritic zone. But different types of human activities destroyed the landscape as well as geodiversity of the study area.

\section{Objectives}

In order to fulfill the aim of the study, the following objectives must be met:

- To provide an assessment and description of the character, distinctiveness and qualities of the landscape of Kansai - Tangai interfluves area of Paschim Medinipore District, identifying their component landscape types and character areas.

- To identify the factors, which have influenced to landscape change in the past, factors, which take part in recent landscape change and those, which will influence change in the future of Kansai - Tangai interfluves area of Paschim Medinipore District. This should also include outside factors which impact locally.

- To promote an integrated approach to action on landscape and biodiversity through the use of 'Remote Sensing data \& GIS tools'.

- To promote awareness of the landscape character and its social significance and the importance of conservation, enhancement and restoration.

\section{Methodology}

The overall approach has been integrated, considering all aspects of landscape including geology, soils, landform, land use, settlement pattern and character, vegetation cover, communication networks, visual and perceptual aspects including tranquility and wilderness of Kansai-Tangai interfluves area of Paschim Medinipore District. The characterization stages of the LCA have been undertaken - desk study, field survey, classification and description, research and analysis (Fig. 1). The desk study provided background information, summarizing the physical, ecological and human forces that have shaped the landscape. Field survey tested and refined the desk study, gathered information about the visual aspects of the landscape and condition of landscape features. The classification and description stage involved identification into appropriate landscape character types, mapping their extent and providing concise written descriptions of their character including key characteristic features of the landscape. Following figure shows the Landscape Character Assessment process (Fig. 2).

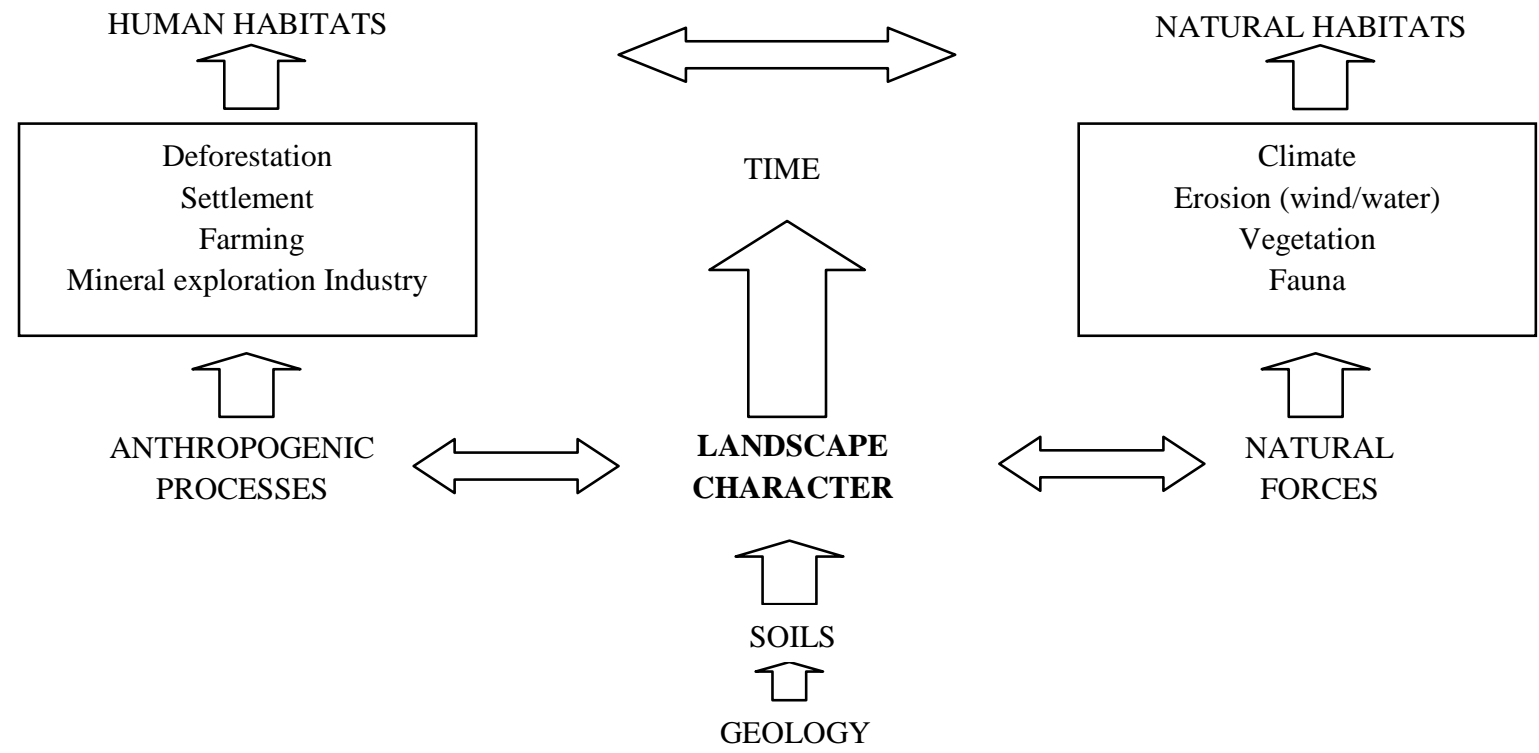

Figure 1. Landscape Characters in Relation to Natural and Anthropogenic Factors. 


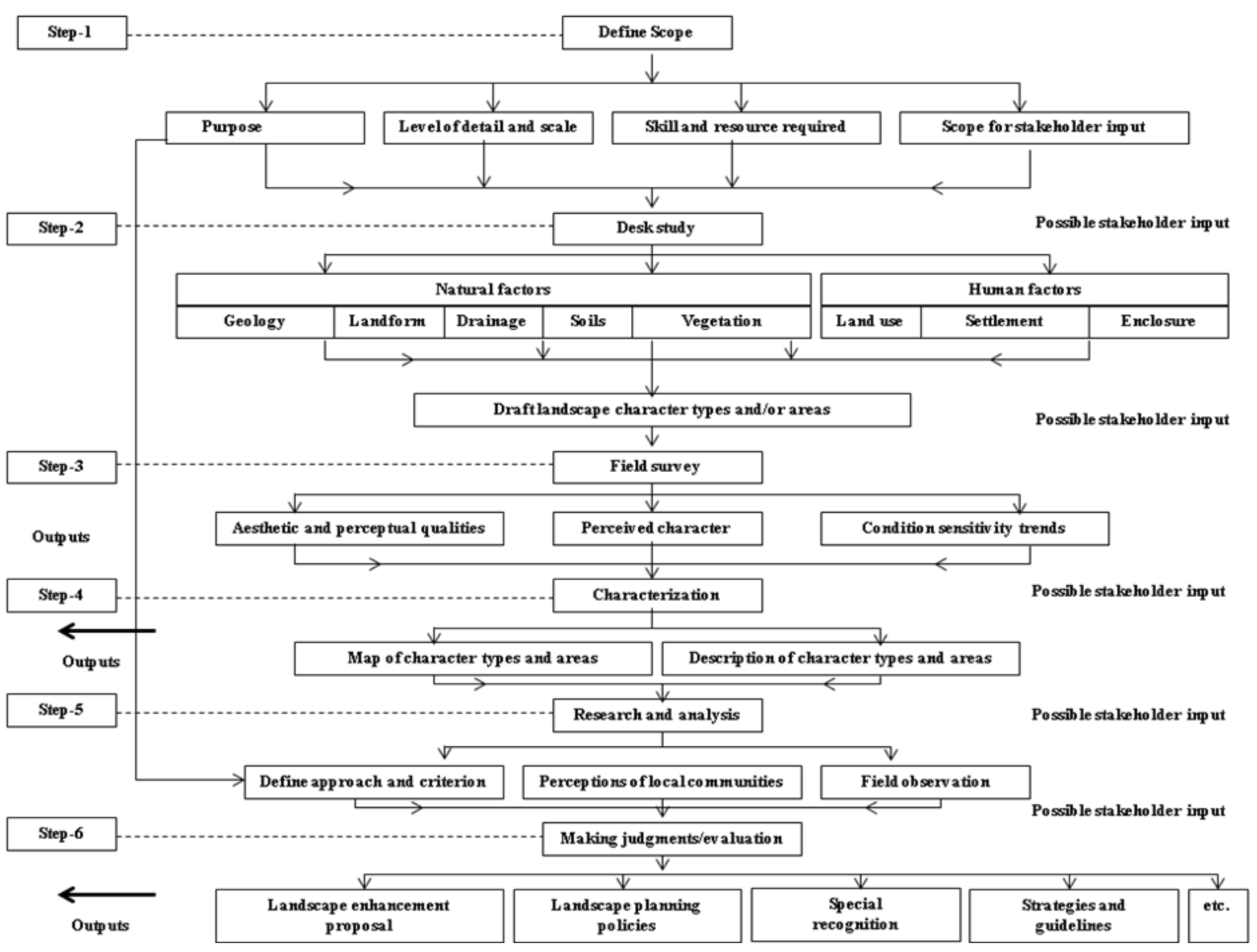

Figure 2. Landscape Character Assessment Processes.

\subsection{Land Use/Land Cover}

VI. Results and Discussion

After the extraction of the study area stratified approach has been adopted to generate land use / land cover output obtained from digital classification of IRS 1D LISS III data by supervised mode with maximum likely hood algorithm using necessary ground truth information (Table 1). Information gathering sites visits pertaining to land use / land cover substantiated the training sets during remotely sensed image classification by MXL classifier (Fig. 3).

Table 2. Land Use/Land Cover with their Land Use Suitability.

\begin{tabular}{|c|c|c|}
\hline Land Use Class & Area (Hec.) & Land Use Suitability \\
\hline Dense forest & 13753.1 & Highly important in eco-system as well as Natural landscape. Area need to conserve. \\
\hline Degraded forest & 3313.5 & $\begin{array}{l}\text { Need to be managed properly with possibilities of new plantation. Important from point } \\
\text { of view of medicinal plantation and agro-forest scheme. }\end{array}$ \\
\hline Cropped area & 21494.51 & $\begin{array}{l}\text { Area under agriculture should not be converted to other scheme. Any infrastructure } \\
\text { development should be restricted. }\end{array}$ \\
\hline Dry fallow & 16115.8 & $\begin{array}{l}\text { It can be used for agro-forest scheme, land reclamation for agricultural use or use for } \\
\text { urban development. }\end{array}$ \\
\hline Wet fallow & 24766.1 & $\begin{array}{l}\text { It can be used as fixed water bodies, cheek dam or dam for rain water storage and } \\
\text { fishing. }\end{array}$ \\
\hline Water bodies & 2993.98 & $\begin{array}{l}\text { It is necessary to keep water body clean and pure as it highly controlled landscape of a } \\
\text { place. }\end{array}$ \\
\hline Lateritic land & 15269.74 & Some portion of lateritic land can be used for plantation. \\
\hline Settlement & 8998.59 & It is a dynamic attribute of landscape. It can destroy or change landscape of a region. \\
\hline Open forest & 5288.52 & $\begin{array}{l}\text { Very important for nature. Area need to be managed and conserved properly to balance } \\
\text { ecosystem as well as landscape. }\end{array}$ \\
\hline
\end{tabular}




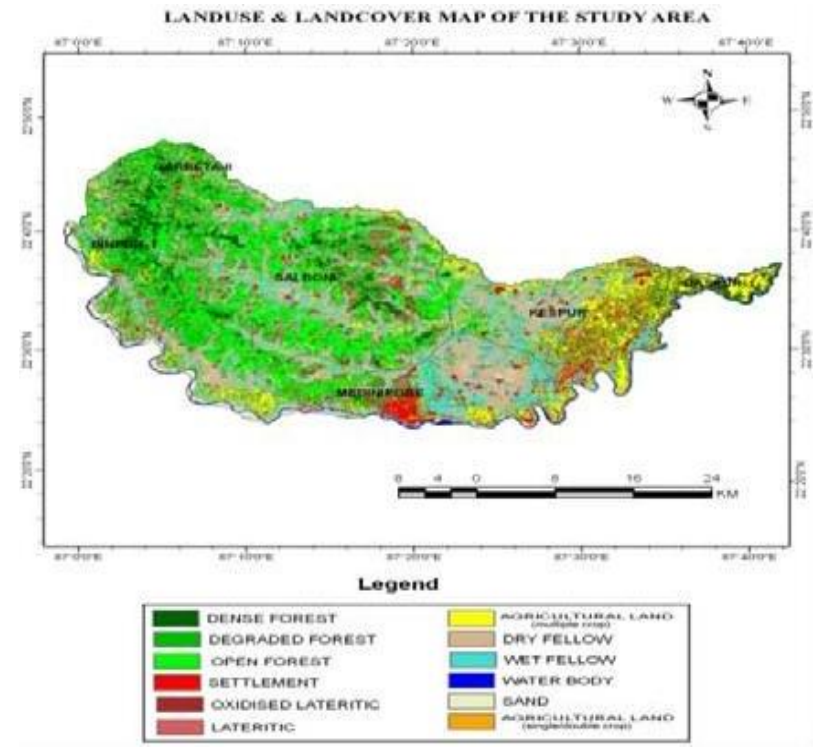

Figure 3. Land Use/Land Cover Map.

\subsection{Dynamic landscape of forest}

The comparative status of the forest covers of Kansai-Tangai interfluves area, as well as Paschim Medinipore during 1995 to 2005 onward has been decreased rapidly. The trends of forest cover shows that during 1995- 2005 maximum deforestation has been done (Table 3).

Table 2. Different Types of Forest Area (1995-2005).

\begin{tabular}{ccccc}
\hline \multicolumn{5}{c}{ Forest Character Type Area (Hec.) } \\
\hline Year & Dense & Open & Degraded & Non forest \\
\hline 1995 & 22327.7 & 10200.61 & 8247 & 16415.32 \\
\hline 2005 & 13753.1 & 5288.32 & 33134.51 & 21283.25 \\
\hline
\end{tabular}

The degradation activities viz. shifting cultivation, clear felling of forests for timber and mining has frequently altered the natural landscape of the study area to a great extent. This has resulted in fragmentation of landscape and loss of many endemic species from the study area (Table 3). There has been significantly increased in landscape variability.

Table 3. Different Types Endemic Species in Forest Coverage (1995-2005).

\begin{tabular}{cccccc}
\hline Forest Type & $\begin{array}{c}\text { No. of } \\
\text { Samples }\end{array}$ & $\begin{array}{c}\text { Total No. of } \\
\text { Species }\end{array}$ & $\begin{array}{c}\text { Economically Important } \\
\text { Species }\end{array}$ & $\begin{array}{c}\text { Medicinally } \\
\text { Important Species }\end{array}$ & $\begin{array}{c}\text { Endemic } \\
\text { Species }\end{array}$ \\
\hline Dense & 60 & 300 & 126 & 67 & 30 \\
Open & 25 & 250 & 105 & 62 & 21 \\
Degraded & 38 & 280 & 102 & 86 & 10 \\
\hline
\end{tabular}

The zone of ecological influences along and around road and settlement respectively was observed to regulate diversity in the study area. It is very fascinating in present study area that diversity is more at medium disturbance level. Accordingly, diversity is lower in the absence of disturbance as well in the presence of too much of disturbance. Landscape analysis concentrates on spatial arrangements of patches, their quality, juxtaposition and the proportion of habitat types that influence and modify the behaviour of species population and communities. Landscape analysis is an important component in determining the diversity of life forms since most of the ecological patterns and processes have unique shaping factors. The elicit felling of forest is very much common in this area which may a major cause of forest fragmentation in these landscapes, in addition with deforestation for agricultural lands and fuel woods collection from forest is also take a considerable part for reducing the forest cover (Fig. 4). Evidence of retrogressive trend, set in the community structures is fragmentation in this area only due to the human population pressure, industrial logging and also for the week government policies. 


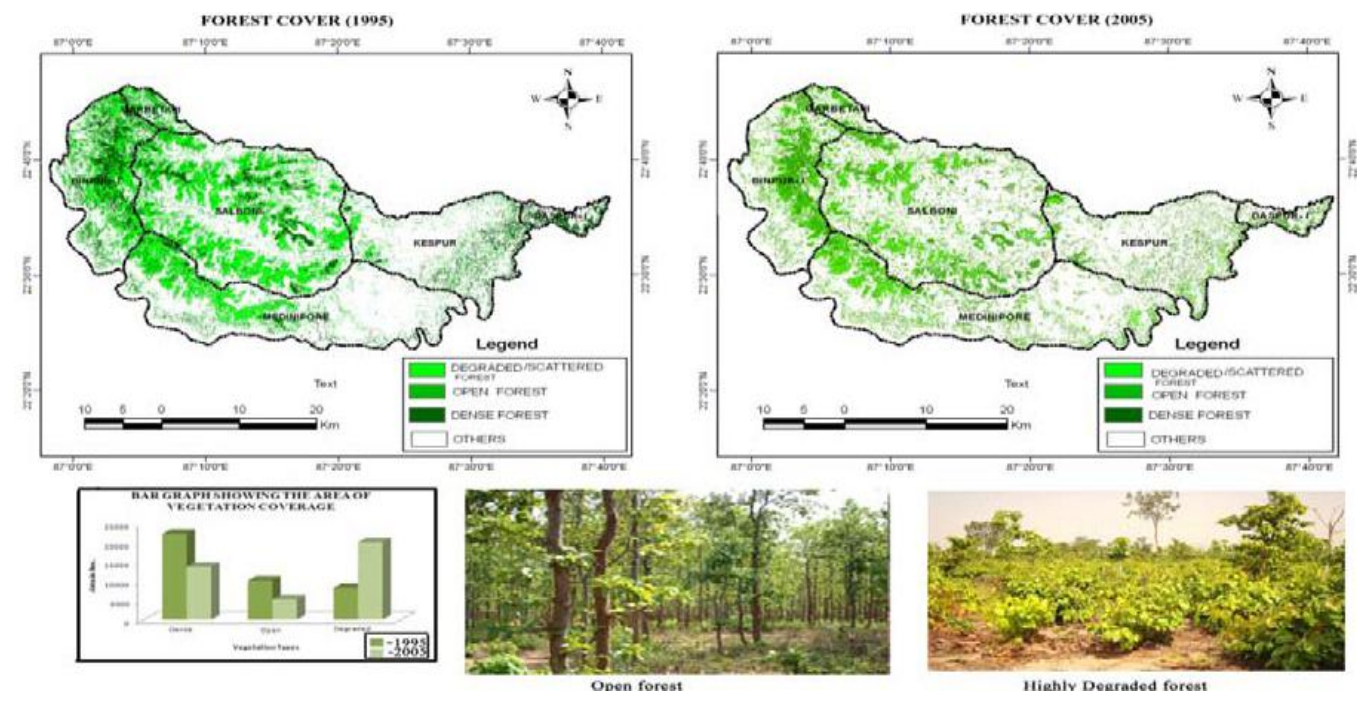

Figure 4. Change Detection of Forest Cover (1995-2005).

\subsection{Agricultural uses of land}

Agriculture is the main source of raw material for numerous agro based industries at study area as well as throughout the India. It also provides employments to a vast numbers of people in the village and towns along with a large part of the market for industrial goods, particularly the farm inputs like fertilizers, pesticides, implements, machinery pumps etc. It brings income to the government by transporting agricultural products from the study area to other part of the country also bring income by exporting to abroad. Above 50 percent values of Indian exports consists of agricultural goods. The agricultural activities of the Kansai-Tangai interfluves area, which supplies not only food grains, beverages and nutritious food like milk and eggs but also sub stains a large number of industries.

In the study area (Kansai-Tangai interfluves region) the amount of agricultural land is 21493.17 hectors out of 124519.76 hectors. Most of the agricultural lands are multicrop land. Single or double crop land area is $8434.91 \mathrm{Hec}$. Most of the agricultural area stretch over Daspur-I and Keshpur blocks of the study area. The distribution of agricultural land of the study area is given below (Fig. 5).

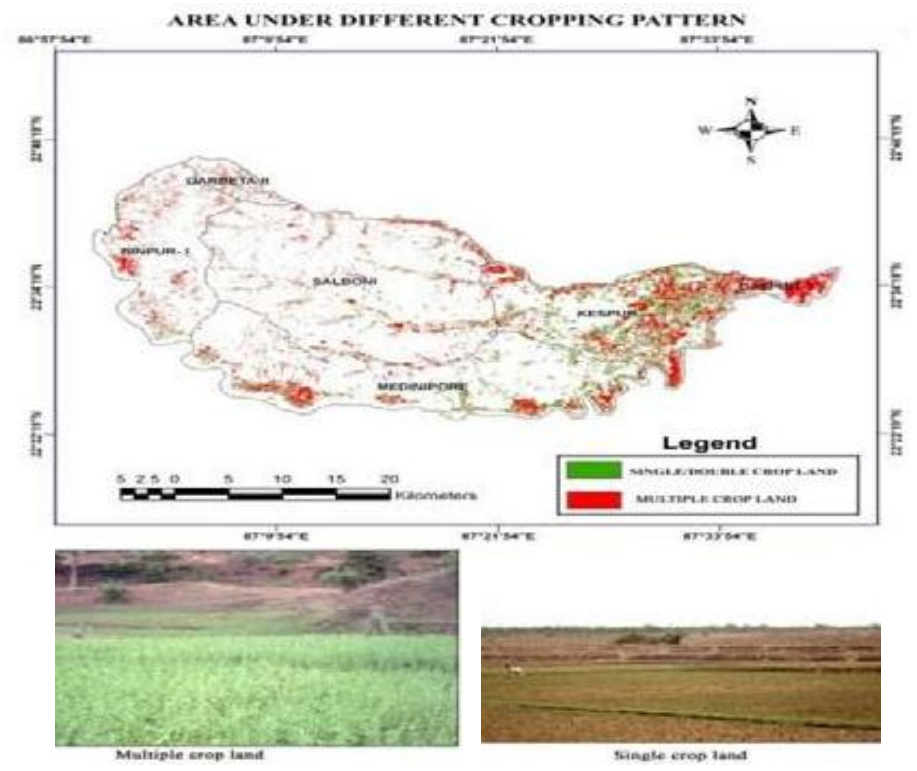

Figure 5. Cropping Pattern and their Areal Distribution.

\subsubsection{Agricultural Impacts on Geodiversity}

In general terms, there is likely to be little damage to geodiversity in areas that have had a long and successful history of cultivation. Farmers who have rotated crops, retained fertility and managed the land to 
prevent soil erosion have been able to conserve and sustain the soil resource. In some cases, however, particular problems may arise. For example, regular ploughing of steep slopes can affect physical integrity of the slopes and landforms by increasing erosion and downs lope movement of soil which is commonly presents in the western part of the study area. In the eastern portion of the said region, where the landforms are small scale and intricate (e.g. low sand dunes or abandoned channels or river terraces), ploughing can reduce the relief and landform detail. But the biggest threats to geodiversity have come from unsustainable land management and the history of land clearance. Land reclamation and bringing it into agriculture that have not previously been cultivated is very much found at the southern part of the study area, which will alter many of the soil properties (e.g. soil compaction, organic matter content and distribution, soil biota, soil chemistry from fertilizer or pesticide application) and reduce natural soil diversity. At the same time intensive agriculture is practiced in the central portion of Kansai-Tangai interfluves region which is also going on year after year, resulting in loss of soil structure and leaching of nutrients. On the other hand beside the town like Midnapore, Kharagpur, Soil compaction has become and increasing problem only due the agglomeration of bigger and heavier farm machinery. Subsoil compaction is frequent in nature in this area, which may occur below the plough layer, producing a "plough-pan". "Nearest the surface, a combination of compaction and tractor wheel-spin may limit the extent to which plant roots can exploit the soil for moisture and nutrients and the free movements of gases between soil and the atmosphere" (Bridges, 1994). Compaction decreases infiltration compactly and porosity, resulting in faster saturation and overdevelopment flow. In turn, soil erosion by wind, water including transport of pesticides residues, siltation or river course and increased flooding may result.

There has been much debate as to whether soil should be regarded as a renewable or non-renewable resource. Although the organic content of soil, derived from dead and living plants and animals, is at least partially replaceable relatively quickly by pioneer vegetation like Sal, Mahua, Palash, leaf falls, colonization by soil fauna and manuring the mineral components may take thousands or millions of years to whether from the parent rock. Thus it is important that soil is regarded as a non-renewable resource in which soil erosion losses are unsustainable even with the addition of fertilizers.

Over ploughing of the said study area may also mean some loss of surface rock exposure and reduce the accessibility of different natural sites. Off-site effects of this area also may include chemical pollution of watercourses or ground water, more rapid runoff and episodic soil erosion.

The application of fertilizers and pesticides to land has already been referred to and can be very beneficial to the quantity and quality of corps yields. However, residues may remain in the soil and excessive amounts may be flushed and leached into surface or ground water, thus leading to nitrate and other pollution and water eutrophication is a common scenario of this agricultural tract. The use of high salt content water in irrigation has also impacted on soil by searching nutrients, changing ground water levels and increasing salinity. The southern portion of the study area is under the high salinity levels zone only due to the over abstraction of ground water. These changing patterns in agricultural practices also have an effect on hydrology in this particular zone.

\section{Settlement Pattern}

A human settlement is defined by geographers as a place inhabited more or less permanently by men and women. However this definition is mainly confined to academic literature in geography. To the common man a settlement or a place of dwelling is identified as a village or a town or a city. The oxford Dictionary has several definitions for the settlement and the one that comes closest to that of the geographer is an assemblage of persons settled in a locality.

The term pattern indicates inter building distance (e.g. clustered and dispersed patterns). The primary distinction is between settlements that are clustered and settlements that are dispersed. In clustered settlement the houses are close to each other with the fields lying outside the village. Inter building distance are small, such a village is described as clustered, compact and nucleated which pattern is mainly found in Midnapore town and some part of Daspur-I and Keshpur blocks . On the other hand dispersed settlements have no compact settlement site. Houses are spread over the village territory with fields and other landuse in the intervening spaces. In the study area dispersed pattern settlement is observed in most of the part of the study are because the high intensity of villages than the town.

\section{Changes in Human Uses of Land}

In past the basic requirements of human beings in this agro-forest based region was very simple and quite. But with the advancement of time the requirements become much. People want to extract resource more from nature to make his life style better. But unscientific acquire of resource from nature, the nature become degraded and lose its balance. There are different types of activities of man presents in this region, which misbalanced the natural environment. 


\section{Mineral Extraction}

As per modern requirements of the studied region extraction of minerals from quarries and other open excavations, including building stone, rock aggregates, metallic ores, sand and gravel, beach shingle, peat and soil is gradually increased. While these activities have frequently going on in the upper catchment area of Kansai-Tangai interfluves region, which resulted in important geological exposures, many of which are subsequently protected, there is also always some loss of geodiversity as the landscape and topography are disturbed and sediments or rock below are removed. This may not be significant where the resource being quarried through a scientific approach, but it will now become frequent, unscientific and problematic even in consign of rare soils, important landforms, limited rock outcrops or important fossil -bearing strata are removed during mineral extraction at the study area. "Mining can be a nasty business; it can be one of the most environmentally damaging activities undertaken by human.....today, more land is devastated because of the direct effects of mining activities than by any other human activity" (Mackenzie, A.F.D., 1998).

\section{Land Development/Urban Expansion}

Rapid growth of urbanization and new building works of these area have also a large impacts on geodiversity by removing topsoil and damaging soil structure and soil biota, removing and re-profiling land surface thus leading to loss of landforms, sub-surface sediments and fossils, and obscuring the underlying rocks and sediments. Urban expansion and infilling in cities like expansion of Midnapore, Kharagpur, Ghatal etc. towns are leading to the accelerating erosion of undeveloped land, and this resulting in loss many important geological sites or semi-natural landscapes. Infrastructure development also often leads to major landscape and pedagogical changes, for example- the construction of road like National High way (NH-6) through the Arabari forest range and Midnapore Bankura and Purulia railways cutting, embankments, dams and reservoirs. Engineering solution such as the use of gabions is often visually intrusive as is the formation of forest roads across mountain slopes.

\section{Threats to Geodiversity}

There is perhaps a general tendency to think of the biological world as fragile and vulnerable and therefore in need of conservation, whereas the a biotic world of mountainous and rock is seen as stable, static and much too prolific ever to be endangered. This is a gross over simplification, and many threats to the geodiversity. Furthermore, geoconservation is not just about protecting the static elements of the landscape. It is also about allowing dynamic processes to continue operating within the historical rang of natural rates. It should also be noted that disturbance to geological, geomorphological and soil process can be produced in ways that are not always local or obvious. For example, individually or cumulatively, vegetation clearance, agriculture, water diversion, forestry and urbanization can all have profound impacts on river landforms and sediments by changing runoff rates ad magnitudes, sediments loads, and so on. There are many significant, real and potentially damaging activities that ought to be better understood if we are to properly conserve and manage geodiversity. The number of threats is great (Glasser, 2001), though only a few are likely to apply in most locations. Many threats are the result of natural processes and human processed. The types of artificial activities that will degrade geodiversity depend on the type's value concerned. Furthermore, the impacts of an operation will depend the sensitivity, suitability or robustness of the site question. An operation that would have a devastating effect in one area may be more acceptable in another, more robust, location. This is because some systems are capable of repairing themselves in a relatively short time due to be continued operation if natural processes, whereas other changes are irreversible because the processes no longer operate or the change to the landscape is fundamental (e.g. removal of an esker by quarrying or loss of soil cover). This concepts of landscape sensitivity is a fundamental one in understanding the threats to geodiversity (Werritty and Brazier, 1994; Gordon et al, 2001).

In general terms threats to geodiversity are the result of development pressure and land-use change, but others may result from natural processes or from human -induced change (e.g. climate change and sea level rise though it is often difficult to separate these effects. The human impacts on geodiversity can be summarized as.

- Complete loss of an elements of geodiversity;

- Partial loss or physical damage;

- Fragmentation of interest;

- Loss if visibility or inter-visibility;

- Loss of access;

- Interruption of natural processes and off-site impacts

- Pollution;

- Visual impacts. 
Some of these impacts affect specific sites of geoconservation value while others impact widely across large land areas, but all may lead to loss of or damage to elements of geodiversity (Table 4).

Table 4. Human Impacts on Geodiversity.

\begin{tabular}{cl}
$\begin{array}{c}\text { Reference } \\
\text { No. }\end{array}$ & \multicolumn{1}{c}{ Type of Operation } \\
\hline 1 & Cultivation, including plugging, rotating, harrowing and reseeding; \\
2 & Grazing and changes in the grazing regime (including types of stock or intensity or seasonal \\
3 & Mining or other methods of cutting the vegetation \\
4 & Application of fertilizer, manure and lime. \\
5 & Dumping, spreading or discharge or any materials. \\
6 & The release into the site of any wild, feral or domestic animal., plant or seed \\
7 & The killing or removal of any wild animal, including pest control. \\
8 & The destruction, displacement, removal, or cutting of any plants or plant remains, including tree, scrub, lichen, fungus or \\
\hline
\end{tabular}

The United Kingdom's Wildlife and Countryside Act (1981) allows for the specification of a standard list of Potentially Damaging Operations". Although some are exclusive to biodiversity interests, many can and do affect geodiversity. English Nature (1998) has also recognized many threats to the country's geoheritage and the have also been included in the following discussion (Table 5).

Table 5. List of the Specific Standard Potential Damage Operation.

\begin{tabular}{|c|c|c|}
\hline Threat & Examples of on-site impacts & Examples of off-site impacts \\
\hline $\begin{array}{l}\text { Mineral } \\
\text { extraction(including } \\
\text { pits, quarries, dune) }\end{array}$ & $\begin{array}{l}\text { Destruction of landform \& sediment } \\
\text { records. Destruction of soils, oil structure, } \\
\text { soil biota. }\end{array}$ & $\begin{array}{l}\text { Contamination of water resources. } \\
\text { Changes in sediment supply to active } \\
\text { systems }\end{array}$ \\
\hline $\begin{array}{l}\text { Land development and } \\
\text { urban expansion }\end{array}$ & $\begin{array}{l}\text { Large-scale damage and disruption of } \\
\text { landforms and soils. } \\
\text { Changes to drainage systems } \\
\text { Creation of slope instability }\end{array}$ & $\begin{array}{l}\text { Changes to processes downstream } \\
\text { contamination of water resources. }\end{array}$ \\
\hline $\begin{array}{l}\text { Forestry, vegetation } \\
\text { growth and engineering }\end{array}$ & $\begin{array}{l}\text { Loss of landform and out crop visibility. } \\
\text { Physical damage to small scale landforms. } \\
\text { Soil erosion. Changing in soil chemistry\& } \\
\text { soil water regime }\end{array}$ & $\begin{array}{l}\text { Increase in sediment yield and runoff } \\
\text { during planting and deforestation. } \\
\text { Changes to ground water and surface } \\
\text { Water chemistry. }\end{array}$ \\
\hline Agriculture & $\begin{array}{l}\text { Damage or loss of small scale landforms } \\
\text { through ploughing, ground water leveling } \\
\text { and drainage. } \\
\text { Soil compaction, loss of organic matter and } \\
\text { soil biota. } \\
\text { Changes to soil chemistry from fertilizers } \\
\text { and effects of pesticide on soil biota. Soil } \\
\text { erosion }\end{array}$ & $\begin{array}{l}\text { Changes in runoff arising from } \\
\text { drainage. } \\
\text { Episodic soil erosion by wind and } \\
\text { water. Pollution of surface and } \\
\text { ground water from excess } \\
\text { agrochemical application. }\end{array}$ \\
\hline
\end{tabular}

\section{Sensitivity Zoning}

Sensitivity concerns the degree to which a particular landscape character type or areas can accommodate change without unacceptable adverse consequence for its character. Capacity is similar and deals with the amount of change of a particular type that a landscape can accept without detrimental effects on landscape character. Robustness is a term used to describe both concepts. A "robust" landscape will have low sensitivity and high capacity to accept change. For example undulating landscapes may be of lower sensitivity, higher capacity and generally more robust in accepting landscape change than flat and featureless landscapes. These are familiar concepts for geomorphologists but perhaps not for most landscape assessors. The map (Fig. 6) is taken as the parameters (geology, topography, geomorphology, drainage sub environment, forest cover, landuse) to evaluate the area of landscape sensitive zone. For this purpose a weighted approach was adopted to identify areas which are ecologically sensitive. The input in the form of ARC /INFO coverage were assigned relative weighted in accordance to its influence/ importance in decision making based on expert opinion, and 
each other class in the individual coverage was ranked according to its potential of being for identification the sensitive areas.

The analysis shows that the areas under agriculture are highly sensitive because of intensive utilization of underground water to irrigate agricultural lands. Furthermore, these areas are associated with fine loamy soils of newer alluvial flat having relatively moderate degree of slope. Thus intensive agriculture has made these areas highly prone to soil erosion. The areas at the toe slopes of the transitional zone are also highly sensitive due to higher degree of slope and intensive agriculture at the cost of forest. Obdurately poor ground water potentially that restricts agricultural practices. Further more highly leached alphisol soils are less fertile but the lateritic upland are less sensitive due to the fact that these lands are less utilized and grossly forested. The natural conditions are fairly presented except deforestation.

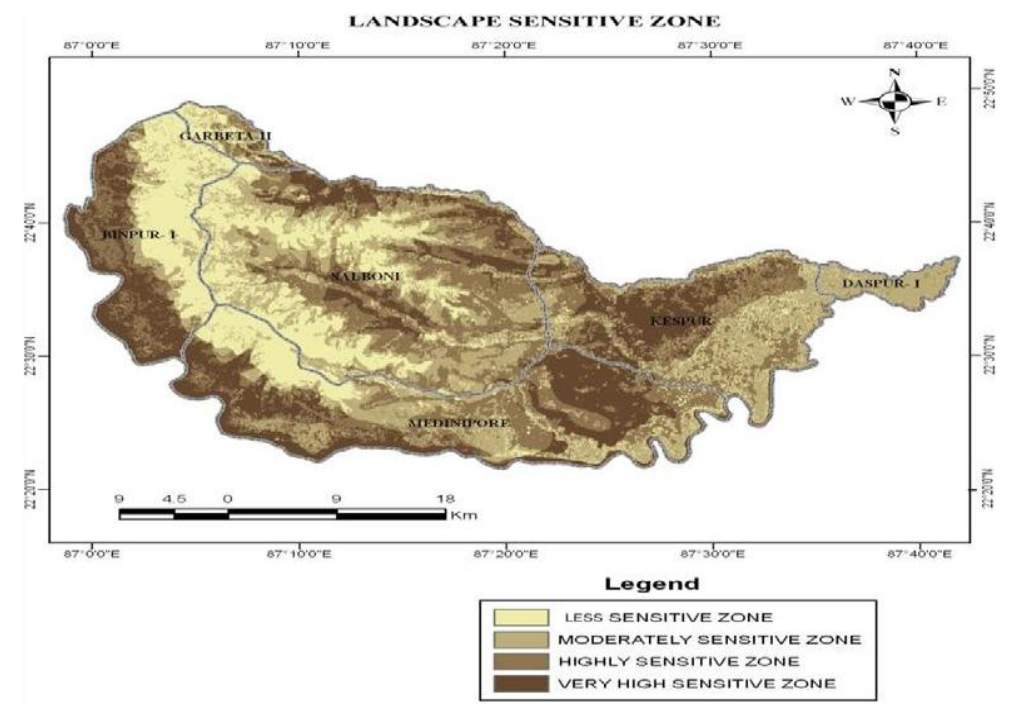

Figure 6. Landscape Sensitive Zones.

XIII. Management Issues

To enhance landscape character four broad geo conservation management options have been developed-

a) Protection

Appropriate in town and its peripheral area, where the exclusion of artificial disturbance is necessary from sites of high significance and/or great sensitivity.

b) Special prescriptions

Appropriate in the buffer area of the said region, where features have a lower sensitivity so that their values can be preserved by special modification of development processes to avoid degradation of the site value.

\section{c) General prescription}

Appropriate in the central part of the studied region, where the site is robust to many artificial disturbance and where general prescription to maintain overall environmental quality (e.g. land management code of practice) are sufficient to maintain site value.

\section{d) Precautionary management}

Appropriate in north and north western forest region, where the management requirements are unknown because of poor understanding or knowledge of the site sensitivity or the response to disturbance. The precautionary principle should apply so that potentially damaging operation are avoided or reduced in intensity until further research is carried out.

\section{Conclusion}

The study shows that the area under agriculture is highly sensitive because of extensive underground water to irrigate agricultural land. Thus extensive unscientific agricultural works have made this area highly degradable. To extend agricultural lands deforestation is also made. This ultimately leads to landscape 
degradation. Again the dry fallows of eastern part of the study area are also highly sensitive. The areas are highly prone to soil erosion because of unscientific uses of land (example- bricks field, excavation zone). Finally the study brings to light that the relation between landscape and sensitivity is inversely proportional, where sensitivity is high, and the landscape become degraded.

\section{References}

[1]. Gordon, J.E., Brazier, V. \& Lees, R.G. (1994) Geomorphological systems: developing fundamental principles for sustainable landscape management. In O'Halloran, D., Green, C., Harley, M., Stanley, M. \& Knill, J. (eds) Geological and Landscape Conservation. Geological Society, London, 185-189.

[2]. Turner, T. (1998) Landscape Planning and Environmental Impact Design. 2nd ed. UCL Press, London.

[3]. McMillan, A.A., Gillanders, R.J. \& Fairhurst, J.A. (1999) The Building Stones of Edinburgh. 2nd ed. Edinburgh Geological Society, Edinburgh.

[4]. Gray, J.M. (1997a) Planning and landform: geomorphological authenticity or incongruity in the countryside. Area, 29, 312-324. Milton, K. (2002) Loving Nature: Towards an Ecology of Emotion. Routledge, London.

[5]. Kiernan, K. (1997a) The Conservation of Landforms of Coastal Origin. Forest Practices Board, Hobart.

[6]. Sharples, C. (2002a) Concepts and Principles of Geoconservation. PDF Document, Tasmanian Parks \& Wildlife Service website.

[7]. Kiernan, K. (1994) The Geoconservation Significance of Lake Pedder and its Contribution to Geodiversity. Unpublished Report to the Lake Pedder Study Group.

[8]. Kiernan, K. (1996) The Conservation of Glacial Landforms. Forest Practices Unit, Hobart.

[9]. Dixon, G. (1995) Aspects of Geoconservation in Tasmania: A Preliminary Review of Significant Earth Features. Report to the Australian Heritage Commission, Occasional Paper 32. Parks \& Wildlife Service, Tasmania.

[10]. Dixon, G. (1996a) Geoconservation: An International Review and Strategy for Tasmania. Occasional Paper 35, Parks \& Wildlife Service, Tasmania.

[11]. Dixon, G. (1996b) A Reconnaissance Inventory of Sites of Geoconservation Significance on Tasmanian Islands. Report to Parks \& Wildlife Service, Tasmania and Australian Heritage Commission.

[12]. Australian Heritage Commission, (2002) Australian Natural Heritage Charter. 2nd ed. Australian Heritage Commission, Canberra

[13]. Sharples, C. (2002a) Concepts and Principles of Geoconservation. PDF Document, Tasmanian Parks \& Wildlife Service website.

[14]. Working plan division, Midnapore. "Second working plan for the revised and protected and unclassed forest of East Midnapore Forest Division (1995 - 2015).

[15]. Bridges, E.M. (1994) Soil conservation: an international issue. In O’Halloran, D., Green, C., Harley, M., Stanley, M. \& Knill, J. (eds) Geological and Landscape Conservation. Geological Society, London, 11-15.

[16]. Mackenzie, A.F.D. (1998). Land, Ecology and Resistance in Kenya, 1880-1952. Routledge, London. Cooke, R.U. \& Doornkamp, J.C. (1990) Geomorphology in Environmental Management. Oxford University Press, Oxford.

[17]. Glasser, N.F. (2001) Conservation and management of the earth heritage resource in Great Britain. Journal of Environmental Planning and Management, 44, 889-906.

[18]. Werritty, A. \& Brazier, V. (1994) Geomorphic sensitivity and the conservation of fluvial geomorphology SSSIs. In Stevens, C., Gordon, J.E., Green, C.P. \& Macklin, M.G. (eds.) Conserving our Landscape. English Nature, Peterborough, 100-109.

[19]. Gordon, J.E., Brazier, V., Thompson, D.B.A. \& Horsfield, D. (2001) Geo-ecology and the conservation management of sensitive upland landscapes in Scotland. Catena, 42, 323-332.

[20]. World Conservation Monitoring Centre, (1992) Global Biodiversity: Status of the Earth's Living Resources. Chapman \& Hall, London. 